\title{
The influence of population structure and reproductive aspects of the genus Stellifer (Oken, 1817) on the abundance of species on the southern Brazilian coast
}

\author{
Rodrigues-Filho, JL. ${ }^{a *}$, Verani, JR. ${ }^{a}$, Peret, AC. ${ }^{a}$, Sabinson, LM. ${ }^{a}$ and Branco, JO. ${ }^{b}$

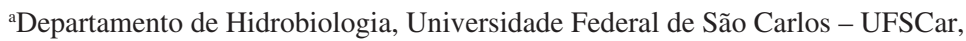 \\ Rod. Washington Luis, Km 235, CEP 13565-905, São Carlos, SP, Brazil

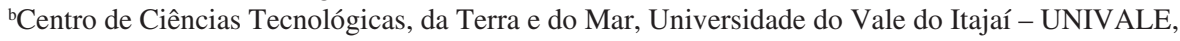 \\ CP 360, CEP 88301-970, Itajaí, SC, Brazil \\ *e-mail: jorlrf@gmail.com \\ Received September 28, 2010 - Accepted December 1, 2010 - Distributed November 30, 2011
}

(With 10 figures)

\begin{abstract}
The differences between abundance and the relationship with aspects of population and reproductive Stellifer rastrifer, Stellifer stellifer and Stellifer brasiliensis were analysed. Data were collected monthly trawl directed for capture of seabob shrimp in Armação do Itapocoroy, an important fishing area on the southern Brazilian coast. The chi-square test showed that the population of $S$. rastrifer presented values of capture significantly higher than others in all evaluated periods. The frequency distribution of total length curves combined with records of the size at first maturity $\left(\mathrm{L}_{50}\right)$ showed that $S$. rastrifer is a species with a majority of the adults effectively participating in the reproductive period. The frequency of occurrence of individuals in reproduction monthly examined together with changes in the gonadosomatic index (GSI) and the reproductive activity index indicated that spring was the main breeding season for the three species. However, it was observed that the reproductive period of S. rastrifer was more pronounced and more extensive than that of its congeners, apparently providing it with ecological advantages and enabling a more effective population balance given the pressure exerted by fishing in the study area.
\end{abstract}

Keywords: fish reproduction, gonadosomatic index, reproductive activity index, population dynamics, bycatch, species coexist.

\section{A influência da estrutura populacional e dos aspectos reprodutivos na abundância de espécies do gênero Stellifer (Oken, 1817) no litoral sul brasileiro}

\begin{abstract}
Resumo
As diferenças nas abundâncias numéricas e a relação dessas com os aspectos reprodutivos e populacionais de Stellifer rastrifer, Stellifer stellifer e Stellifer brasiliensis foram analisadas. Os dados foram coletados em arrastos mensais destinados à captura do camarão sete-barbas em Armação do Itapocoroy, uma importante área pesqueira do litoral sul brasileiro. O teste de qui-quadrado demonstrou que a população de $S$. rastrifer apresentou valores de captura significantemente superiores que as demais em todos os períodos avaliados. A distribuição em classe de tamanho sobreposta ao valor de primeira maturação sexual $\left(\mathrm{L}_{50}\right)$ evidenciou que $S$. rastrifer foi a espécie com a maior proporção de indivíduos capturados considerados adultos, ou seja, que efetivamente participam do evento reprodutivo. A frequência de ocorrência mensal dos estádios de maturação sexual analisada conjuntamente com as variações do índice gonadossomático e do índice de atividade reprodutiva indicaram que a principal estação reprodutiva para as três espécies foi a primavera, Entretanto, observou-se que o período reprodutivo de $S$. rastrifer foi mais acentuado e mais extenso do que o de suas congenéricas, aparentando lhe fornecer vantagens ecológicas e possibilitando um equilíbrio populacional mais eficaz frente à pressão exercida pela pesca na área de estudo.
\end{abstract}

Palavras-chave: reprodução de peixes, índice gonadossomático, índice de atividade reprodutiva, dinâmica de populações, fauna acompanhante, coexistência de espécies. 


\section{Introduction}

The genus Stellifer (Oken) belongs to the family Sciaenid and comprises 24 species of fish that inhabit the coastal regions of the Atlantic and Pacific along the north, central and South American coast (Froese and Pauly, 2010). Along the Brazilian coast, there are six species. Whilst Stellifer stellifer (Bloch), Stellifer rastrifer (Jordan), Stellifer brasiliensis (Schultz) and Stellifer sp. can be found along the whole stretch of coast, the species Stellifer naso (Jordan) and Stellifer microps (Steindachner) are restricted to northeastern and northern Brazil (Menezes et al., 2003).

Populations of Stellifer spp. are frequent and abundant in trawl fisheries carrying out shrimp catches, especially in seabob shrimp Xiphopenaeus kroyeri (Heller) fisheries, due to habitat overlap among these species (Menezes and Figueiredo, 1980). Based on specific composition of the fish fauna data gathered from shrimp trawls conducted in several localities, it is quite notable that $S$. rastrifer is invariably more abundant than its congeners (Giannini and Paiva-Filho, 1990a; Chaves and Vendel, 1998; Graça-Lopes et al., 2002; Sousa and Chaves, 2007; Souza et al., 2008), although all share the same habitat and have great morphological similarity (Menezes and Figueiredo, 1980). For over a decade, the monitoring of the associated fauna in a fishing area confirms the numerical predominance of $S$. rastrifer in relation to the other species (Branco and Verani, 2006).

The analysis of reproductive traits may aid understanding of the differences in numerical occurrences of these species. Previous studies have addressed aspects related to the population of the above species separately, being only describing without inter-specific comparisons (Coelho et al., 1985, 1987; Giannini and Paiva-Filho, 1990b, 1995; Chaves and Vendel, 1997; Almeida and Branco, 2002).

Therefore, this study aims to test the following hypotheses: a) whether there are differences between the abundances of species of the genus Stellifer spp. caught as bycatch in Armação do Itapocoroy; b) If existing, can these differences be explained by the population structure and reproductive patterns of the three species?

\section{Material and Methods}

\subsection{Study area and data collection}

Armação do Itapocoroy (26 $40^{\prime}-26^{\circ} 47^{\prime} \mathrm{S}$ and $48^{\circ} 36^{\prime}-$ $\left.48^{\circ} 38^{\prime} \mathrm{W}\right)$, located in the municipality of Penha, Santa Catarina state, is a traditional fishing area of the seabob shrimp, (Xiphopenaeus kroyeri), in southern Brazil (Branco and Verani, 2006). Samples were collected once a month from April 2007 to February 2008 in three traditional fishing spots of seabob shrimp (Figure 1).

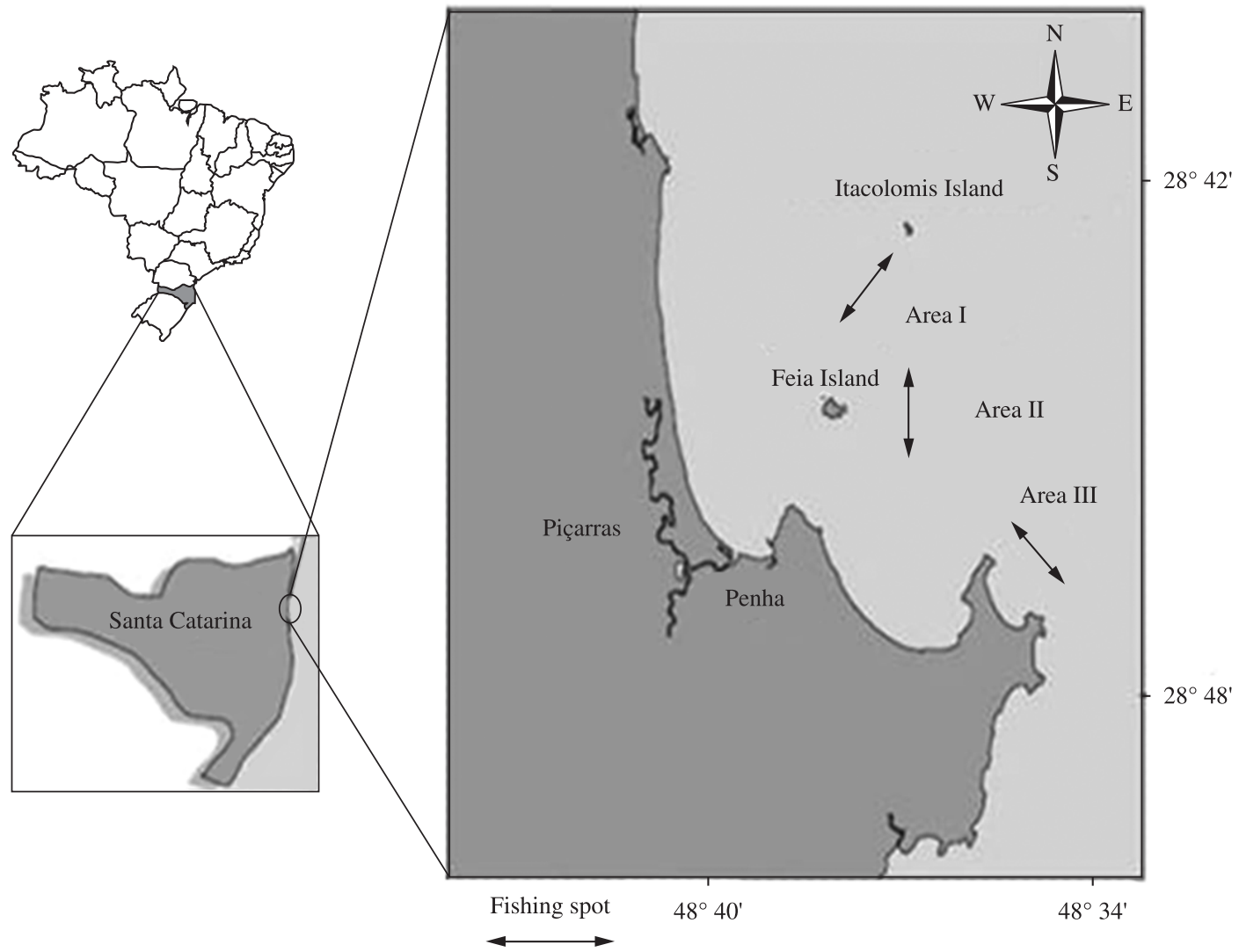

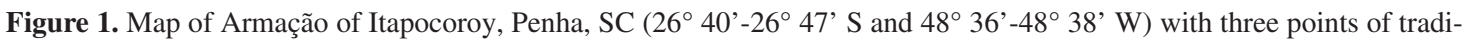
tional fisheries of sea bob shrimp where sampling was conducted. 
A single boat (double-rigged) for bottom trawling was used (Galbraith et al., 2004) with a trawl of $3.0 \mathrm{~cm}$ mesh in the wings, square, belly, baitings and extension and $2.0 \mathrm{~cm}$ at the cod end, towed by a boat at an average speed of 2.0 knots. Three half-hour replicas were done in each traditional fishing spot, totalling 108 trawls (54 hours).

The material caught was placed in plastic bags, labelled with details of the date and site of collection, packed in cooler boxes for subsequent screening.

Stellifer spp. were separated from the fish fauna originated from shrimp trawls and identified to species level based on morphological features according to Menezes and Figueiredo (1980). In the laboratory, the total length and weight of each specimen were recorded to an accuracy of $1.0 \mathrm{~mm}$ and $0.01 \mathrm{~g}$, respectively.

Specimens were then slit open from the urogenital orifice and their gender and level of gonad maturation were determined according to Vazzoler (1996). They were thus classified into four stages: A (immature), B (maturing), $\mathrm{C}$ (mature) and D (emptied). The gonads were weighed on a Sciencetech SA210 scale accurate to $0.0001 \mathrm{~g}$.

\subsection{Data analyses}

The reliability of the data for the study of population dynamics of each species in the area was checked using the total number of fish caught and the number of monthly samples for its calculations on a scale of 0 to 5+ (Pauly, 1984).

The hypothesis of difference abundance for seasonal and annual congeneric species in the region was tested by comparing the frequency of occurrence of each specie by Chi-square $\left(\chi^{2}\right)$ test with $p=0.05$ (Zar, 1999). For the seasonal analysis, months were grouped into: autumn (April, May, and June), winter (July, August, September), spring (October, November, December) and summer (January, February, March).

Annual and seasonal variations of the population structure were analysed with the help of frequency distributions of total length classes (range of $1.0 \mathrm{~cm}$ ). From the frequency distribution of total length classes for the studied species, by analysing the occurrence of individuals in small size classes, recruitment period can be estimated.

Using the values of the total weight and the gonad weight of the individuals, the gonadosomatic index (GSI) was calculated according to Santos (1978). The Kruskal Wallis test $(\mathrm{p}=0.05)$, complemented by Dunn's Multiple Comparisons Test, was applied to the GSI data intending to identify differences among the values of the species (Zar, 1999).

The GSIs of females were used for the calculation of the reproductive activity index $(R A I)$, considering the categories: null (RAI 2); incipient ( $2<$ RAI 5); moderate ( $5<$ RAI 10$)$; intense $(10<$ RAI 20$)$; and very intense (RAI > 20) (Agostinho et al., 1993).

To determine the period of reproduction for each Stellifer species, the monthly variations of the average values of GSI, the frequency of occurrence of individuals in maturation (stage $\mathrm{B}$ ) and in reproduction (stages $\mathrm{C}$ and D) and the values of RAI were analysed. Size at first maturity $\left(\mathrm{L}_{50}\right)$ and size when the whole population was mature $\left(\mathrm{L}_{100}\right)$ were obtained (Santos, 1978).

The combination of the records of the female's $\mathrm{L}_{50}$ and the length frequency distribution curves permitted an estimate of the fishing impact on the different Stellifer population's strata (young and adults). Use of the L50 of females is justified because these reach sexual maturity with values usually greater than that of males (Vazzoler, 1996), which leads to greater reliability on the strata (young or adult) in which the individuals were.

The sex ratio was estimated monthly and the Chisquared $\left(\chi^{2}\right)$ test with Yates's correction (Pearson, 1947) was applied to detect significant differences $(\mathrm{p}<0.05)$.

The length-weight relationship was analysed for the three species and the values of slope (b) were compared by analysis of covariance (ANCOVA) with $\mathrm{p}=0.05$ (Zar, 1999). The condition of the fish in the sampling areas was established with the condition factor $(\mathrm{K})$ and by the relative condition factor $\left(\mathrm{K}_{\mathrm{r}}\right)$ (Le Cren, 1951). The three series of $\mathrm{K}_{\mathrm{r}}$ were compared using the Kruskal Wallis test supplemented by the non-parametric Dunn's test ( $p=0.05)$, as in Zar (1999) and the average values of Kr were compared with the central value 1.0 (Le Cren, 1951).

\section{Results}

A total of 1396 S. rastrifer, 839 S. brasiliensis, 570 S. stellifer and 23 Stellifer $\mathrm{sp}$. were collected during the sampling period.

The values of reliability of the sample data were 5 for S. rastrifer, 4 for S. brasiliensis and S. stellifer and 0 for Stellifer $\mathrm{sp}$. The low value for Stellifer sp. hampers the analysis of population dynamics of this population.

The chi-square test showed that there were significant numerical differences between species in the study area $(\mathrm{p} \geq 0.05)$ and $S$. rastrifer was the dominant species in all analysed periods (Figure 2).

Captured specimens of $S$. rastrifer had an average length of $8.09 \mathrm{~cm}$, which was the greatest total length among the species. The length of this species varied between 3.6 and $20.2 \mathrm{~cm}$. However $74.07 \%$ were in the range 5.0 to $9.0 \mathrm{~cm}$ (Figure $3 \mathrm{a}$ ) with the most numerous classes 5.0 and $6.0 \mathrm{~cm}$.

The specimens of S. stellifer in the catch ranged in total size from 3.4 to $17.2 \mathrm{~cm}$, but the majority were below $8.0 \mathrm{~cm}$. The average size was $6.7 \mathrm{~cm}$ and the modal class was $5.0 \mathrm{~cm}$, followed by classes of 6.0 and $7.0 \mathrm{~cm}$ (Figure $3 \mathrm{~b}$ ).

The average total length of $S$. brasiliensis was $7.6 \mathrm{~cm}$, with a range between 3.3 and $17.0 \mathrm{~cm}$, the most numerous classes being those of 4.0 to $9.0 \mathrm{~cm}$, which represented $87.72 \%$ of the total catch of this species. The modal classes were $6.0 \mathrm{~cm}$, with $21.33 \%$, and $7.0 \mathrm{~cm}$, with $20.86 \%$ (Figure 3c).

The seasonal frequency distributions of total length for the species of Stellifer spp. showed that the frequency of small individuals was highest in the summer (January, February, March), indicating that this is the main period 


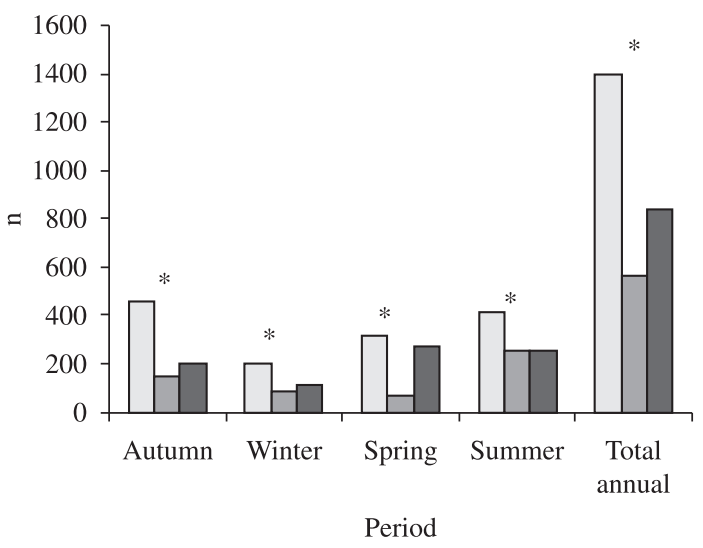

$\square$ S. rastrifer $\quad \square$ S. stellifer $\square$ S. brasiliensis

Figure 2. Seasonal and annual abundance of species of the Stellifer spp. captured in Armação of Itapocoroy, Penha, SC, during the period April 2006 to March 2007. *indicates statistical differences between the abundances of species $(p<0.05)$, i.e., $\chi^{2}$ calculated $>\chi^{2}$ critical.
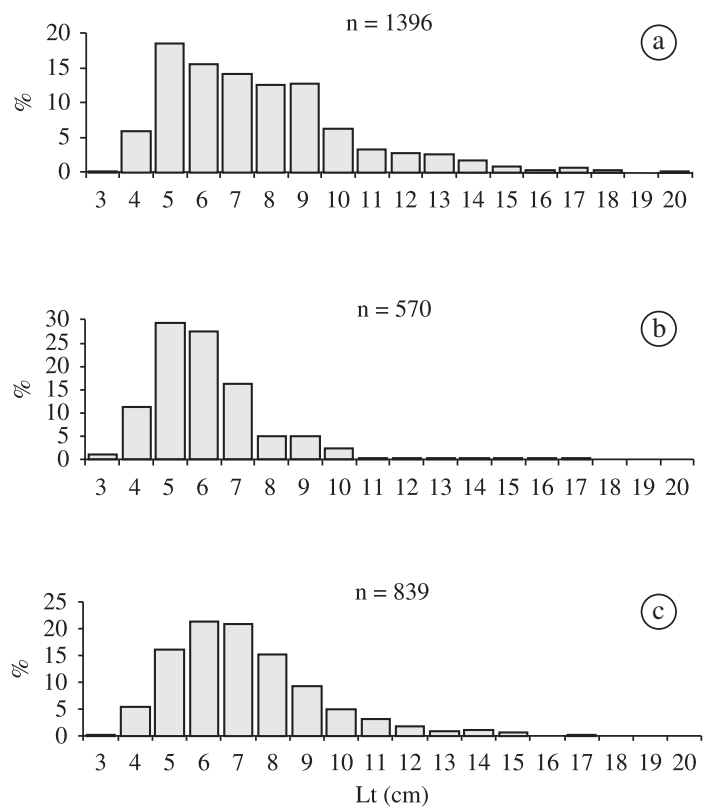

Figure 3. Frequency (\%) of the total length of classes Stellifer rastrifer, Stellifer stellifer and Stellifer brasiliensis captured in Armação of Itapocoroy, Penha, SC, during the period April 2006 to March 2007.

of recruitment of the young ones. The spring (October, November and December) exhibited the highest frequency of larger individuals and this appears to be related to the reproductive period of the three species (Figure 4)

The GSI variations of $S$. rastrifer indicate the reproductive period may start at the end of winter (September) and reach its peak during spring (October and November) (Figure 5a). In the following months, the fall in GSI indicates the spawning period. A second increase, though to a lesser extent, in this index can be seen in summer (February) indicating another spawning period at the end of summer (March). Macroscopic analysis of the female gonads showed that during the months of highest values of GSI there is a high frequency in the population of individuals at stage $\mathrm{C}$ of gonad maturation, while in the subsequent months (November / December and March/ April) there is a high frequency of individuals at stage D (empty), indicating that spawning occurs in those months.

The plot of monthly average values of GSI for S. stellifer suggests that the species has a reproductive period that extends from the winter (August and September)/spring (December) until the summer (January, February and March), with greatest intensity in spring (Figure 5b). Outside these periods, the species had a high frequency of individuals whose gonad morphology was effectively at the start of maturation, stage B.

The distribution of monthly average GSI values of female $S$. brasiliensis (Figure 5c) indicated that the reproductive period starts from the winter (August and September)/spring (October, November and December) and extends until the summer (January and February); this is corroborated by the greater frequency during this period of females in the advanced stages of gonad maturation (stages $\mathrm{C}$ and D).

The Kruskal-Wallis test showed significant difference between the values of GSI species ( $\mathrm{p} \geq 0.05$ ). According to the Dunn test, $S$. rastrifer differently from the others $(\mathrm{p} \geq 0.05)$ and $S$. stellifer and S. brasiliensis showed no significant differences $(\mathrm{p}<0.05)$.

The Reproductive Activity Index (RAI) showed that the peak of reproductive activity occurred during spring, and reproduction activity was categorized as intense for the three populations studied. In summer, the reproductive activity for $S$. rastrifer was considered moderate and for the others species null (Figure 6).

The estimated values of $\mathrm{L}_{50}$ and $\mathrm{L}_{100}$ for females were, respectively, 8.2 and $14.6 \mathrm{~cm}$ for $S$. rastrifer, 7.7 and $11.8 \mathrm{~cm}$ for S. stellifer and 9.4 and $13.2 \mathrm{~cm}$ for S. brasiliensis (Figure 7). The $\mathrm{L}_{50}$ for males were 7.0, 7.2 and 8.7 for S. rastrifer, S. stellifer and S. brasiliensis, respectively (Figure 7)

The overlapping of the female's estimated values of $\mathrm{L}_{50}$ to the frequency distribution of length graphics, demonstrated that fishing on the Armação do Itapocoroy captures predominantly small sized individuals that have not reached sexual maturity. Comparing the effect of fishing on different populations, it was noted that a large percentage (90\% of S. stellifer, $87 \%$ of S. brasiliensis and about $67 \%$ of $S$. rastrifer) of the catch consisted of young individuals (Figure 8).

The collected specimens of all three species were composed mainly of females (Table 1). The ratio of males to females among $S$. rastrifer for the period was 1: 2.03. S. stellifer demonstrated the highest proportion of females among the three species, with a ratio of $1: 2.53$, and $S$. brasiliensis demonstrated a sex ratio of $1: 2.33$. 

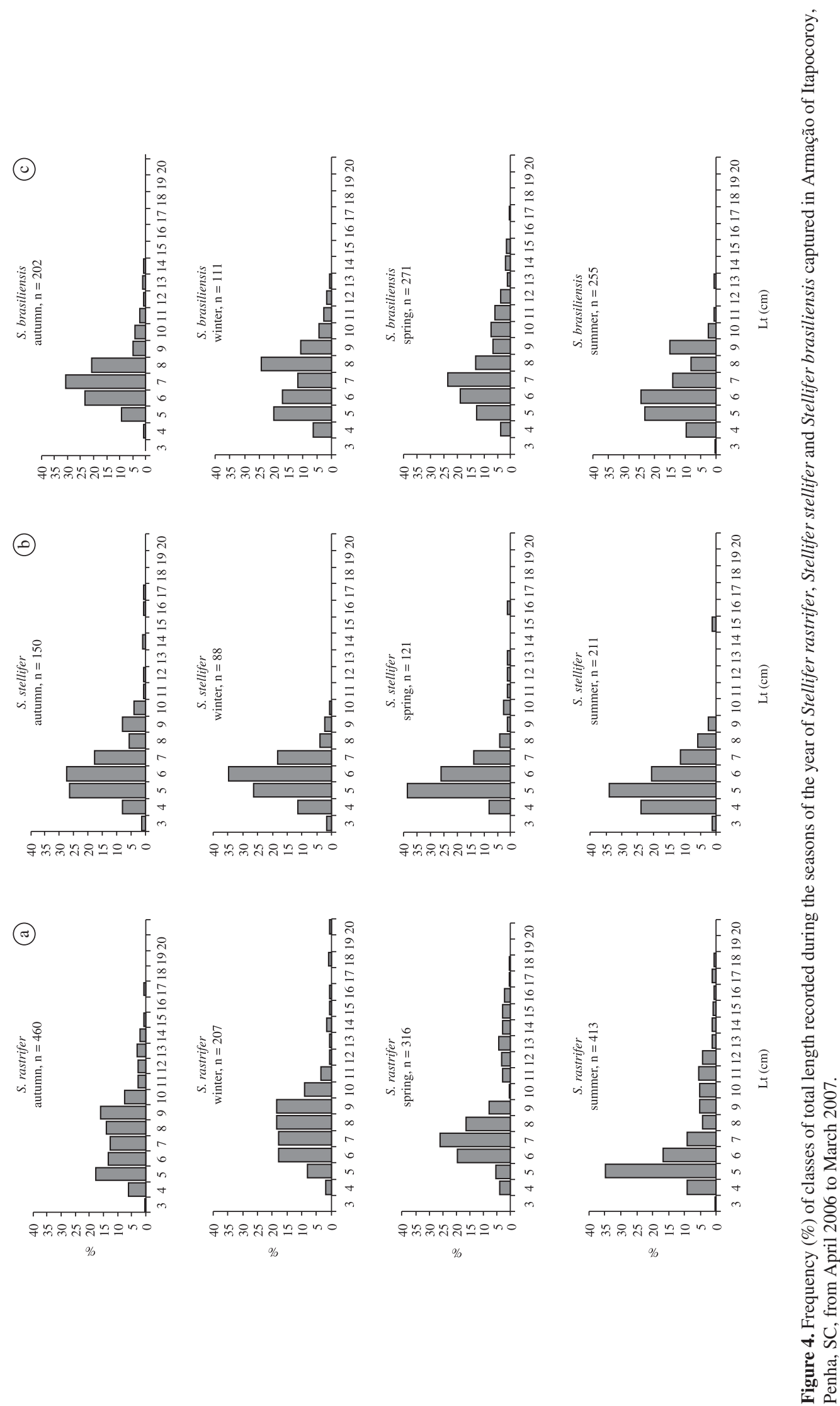

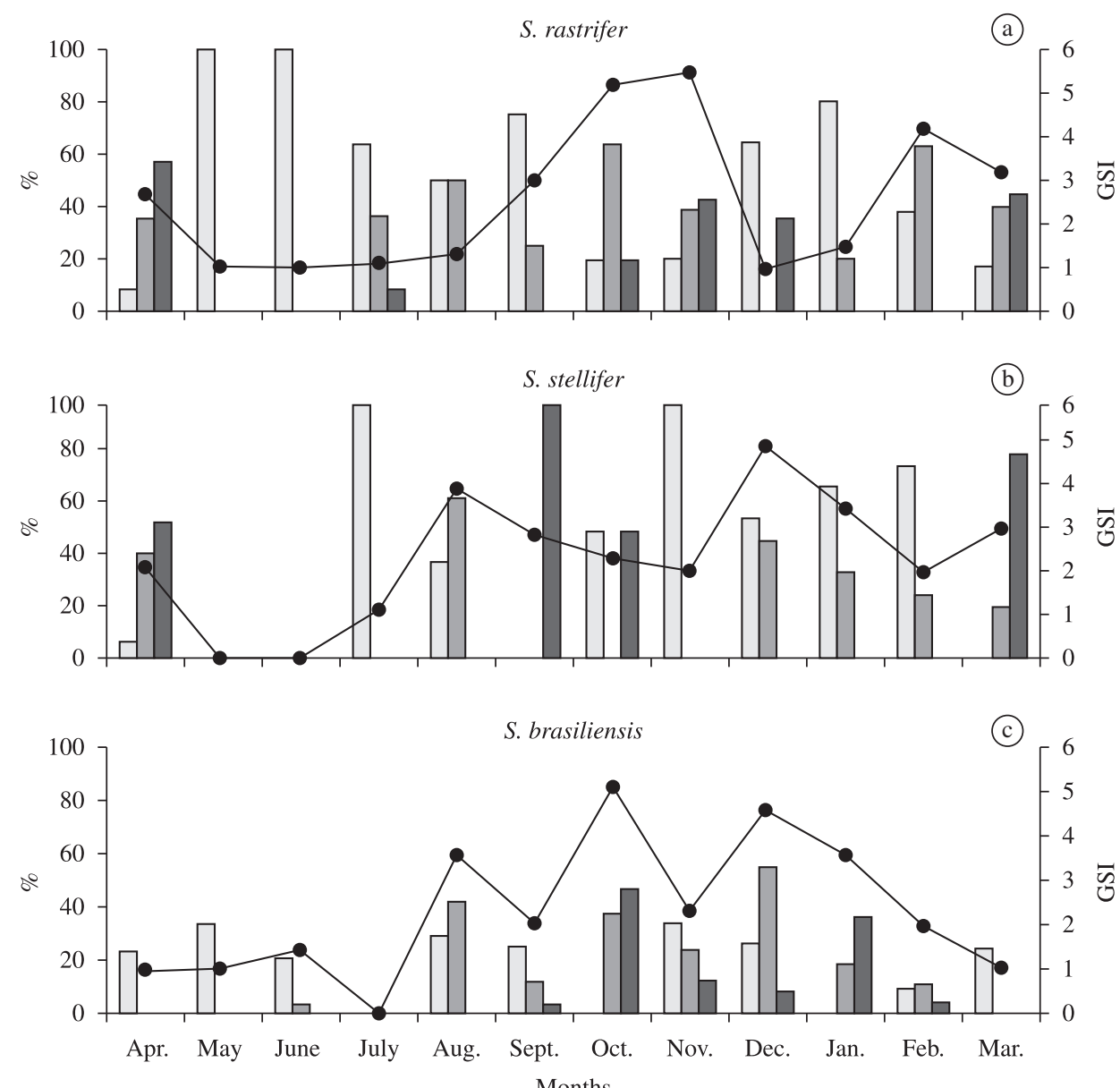

Months

$\square$ Stage B $\square$ Stage C $\square$ Stage D $\rightarrow$ GSI

Figure 5. Frequency of stages of gonad maturation and monthly change of average values of female's Gonadosomatic index GSI of S. rastrifer, S. stellifer and S. brasiliensis caught in Armação do Itapocoroy, Municipality of Penha, SC.

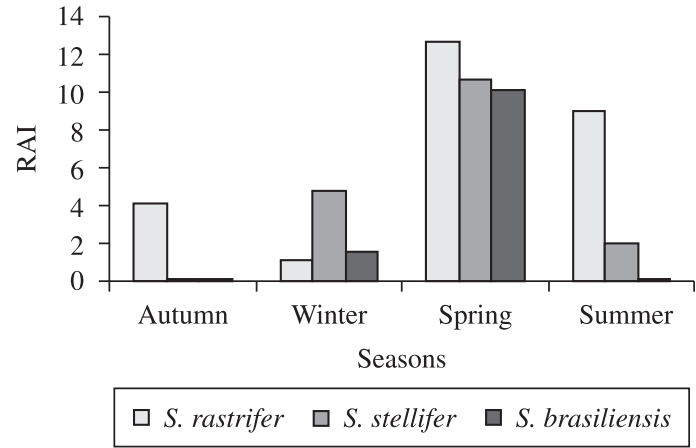

Figure 6. Reproductive activity index (RAI) of Stellifer rastrifer, Stellifer stellifer and Stellifer brasiliensis caught in Armação do Itapocoroy during the period April 2006 to March 2007.

The total weight of the $S$. rastrifer was plotted against total length, resulting in the following equation: $\mathrm{W}_{\mathrm{t}}=0.0065 \mathrm{~L}_{\mathrm{t}}^{3.2613}$. This equation was linearised by applying a logarithmic transformation to the variables, resulting
Table 1. Monthly proportion of male (M)/female (F) of Stellifer rastrifer (a), Stellifer stellifer (b) and Stellifer brasiliensis (c) sampled in Armação do Itapocoroy.

\begin{tabular}{lccc}
\hline \multicolumn{1}{c}{ Month } & M:F (a) & M:F (b) & M:F (c) \\
\hline Apr./06 & $1: 1.92^{*}$ & $1: 3.00^{*}$ & - \\
May & $1: 2.54^{*}$ & - & $1: 2.78^{*}$ \\
June & $1: 1.75^{*}$ & - & $1: 3.25^{*}$ \\
July & $1: 2.08^{*}$ & $1: 2.60^{*}$ & - \\
Aug. & - & $1: 1.50^{*}$ & $1: 1.07$ \\
Sep. & $1: 1.87^{*}$ & $1: 7.00^{*}$ & $1: 2.70^{*}$ \\
Oct. & $1: 1.54^{*}$ & $1: 3.00^{*}$ & $1: 2.75^{*}$ \\
Nov. & $1: 0.67^{*}$ & $1: 3.33^{*}$ & $1: 1.29$ \\
Dec. & $1: 3.37^{*}$ & $1: 3.67^{*}$ & $1: 2.25^{*}$ \\
Jan./07 & $1: 1.46$ & $1: 2.03^{*}$ & $1: 1.75^{*}$ \\
Feb. & $1: 1.20$ & - & $1: 2.67$ \\
Mar. & $1: 2.49^{*}$ & $1: 1.36$ & $1: 2.70$ \\
Total & $1: 2.03^{*}$ & $1: 2.53^{*}$ & $1: 2.33^{*}$ \\
\hline
\end{tabular}

$*$ There was a significant difference $(\mathrm{p}<0.05)$. 

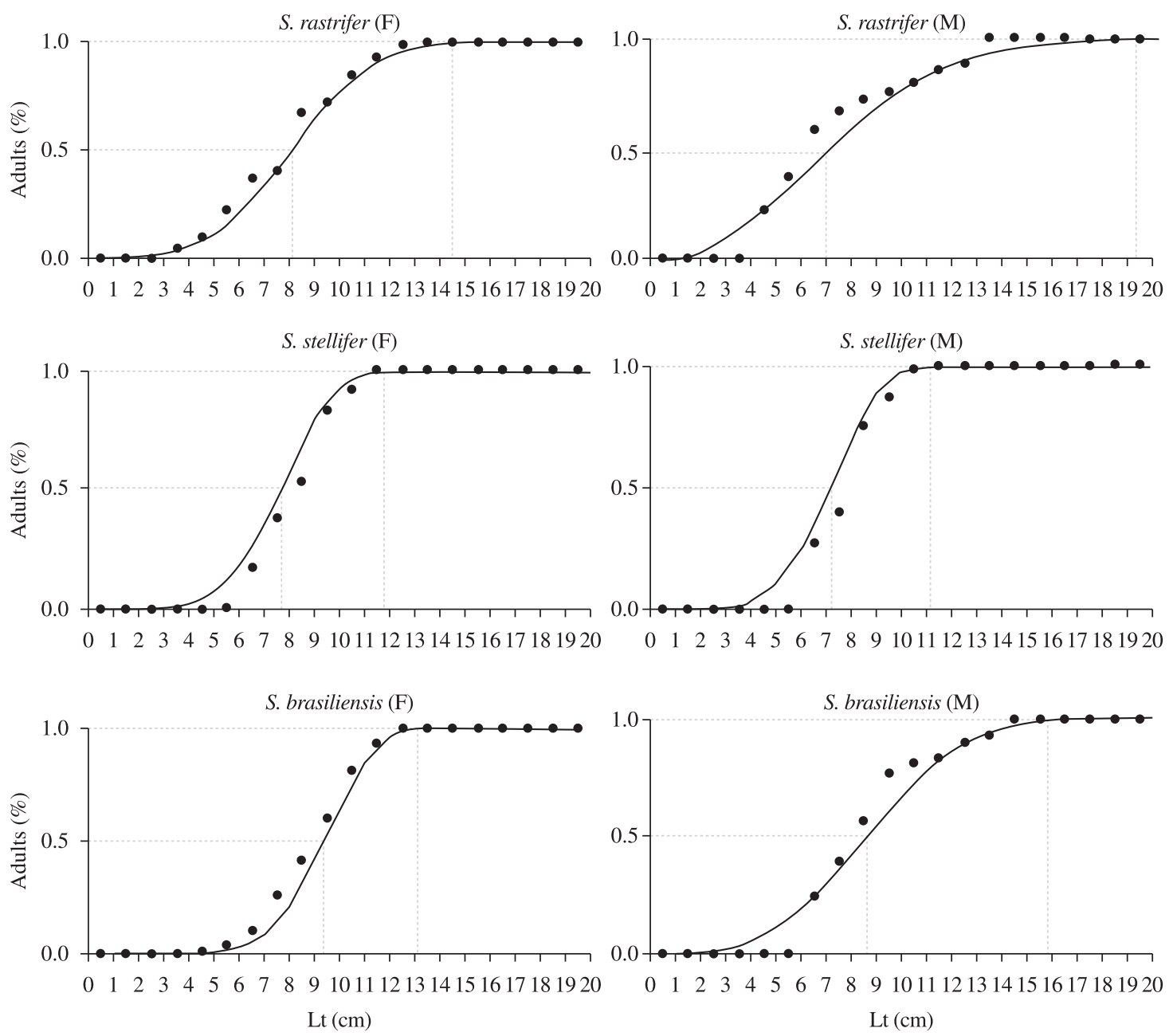

Figure 7. Curve of size of the first maturity of Stellifer rastrifer, Stellifer stellifer and Stellifer brasiliensis in Armação do Itapocoroy, Penha, SC. $*(\mathrm{~F})$ and $(\mathrm{M})$ means female and male, respectively.

in a coefficient of determination $\left(\mathrm{r}^{2}\right)$ of 0.9763 , which was the highest value obtained among the three species (Figure 9). The weight-length relationship for S. stellifer was $\mathrm{W}_{\mathrm{t}}=0.0073 \mathrm{~L}_{\mathrm{t}}^{3.1752}$, with $\mathrm{r}^{2}=0.952$ for the linearised equation (Figure 9). S. brasiliensis also showed a similar trend, with the equation $\mathrm{W}_{t}=0.0079 \mathrm{~L}_{t}^{3.1283}$, whose linear form had a coefficient of determination $\mathrm{r}^{2}=0.9451$ (Figure 9). According to multiple comparison test (ANCOVA) applied to the slopes (b) of the above equations, there were no statistically significant differences between the values of $b(p<0.05)$, indicating that these species have the same growth pattern

The average value of condition factor $(\mathrm{K})$ for S. rastrifer reached a maximum in winter and declined through the year, reaching its lowest point in the summer. S. stellifer and $S$. brasiliensis showed higher values in the fall and, like $S$. rastrifer, showed a gradual reduction until summer (Figure 10).

When comparing the values of relative condition factor $\left(\mathrm{K}_{\mathrm{r}}\right)$ of the population by Kruskal-Wallis test, a significant statistic difference between samples was observed ( $\mathrm{p}<0.001)$. According to the Dunn test, there was no statistical difference between $S$. rastrifer and S. stellifer $(\mathrm{p} \geq 0.05)$. However, when these were compared with $S$. brasiliensis, a significant difference was observed $(\mathrm{p}<0.05)$.

\section{Discussion}

The ichthyofauna caught incidentally by the trawls directed for the capture of seabob shrimp in Armação do Itapocoroy, was characterised by a considerable amount of fish of the genus Stellifer spp. as supported by the study of Branco and Verani (2006). The numerical dominance of $S$. rastrifer compared to its congeners is similar at other locations along the southern and southeastern Brazilian coasts (Giannini and Paiva-Filho, 1990a; Chaves and Vendel, 1998; Graça-Lopes et al., 2002; Sousa and Chaves, 2007; Souza et al., 2008). Although the abundance of S. stellifer and S. brasiliensis is significantly lower than 

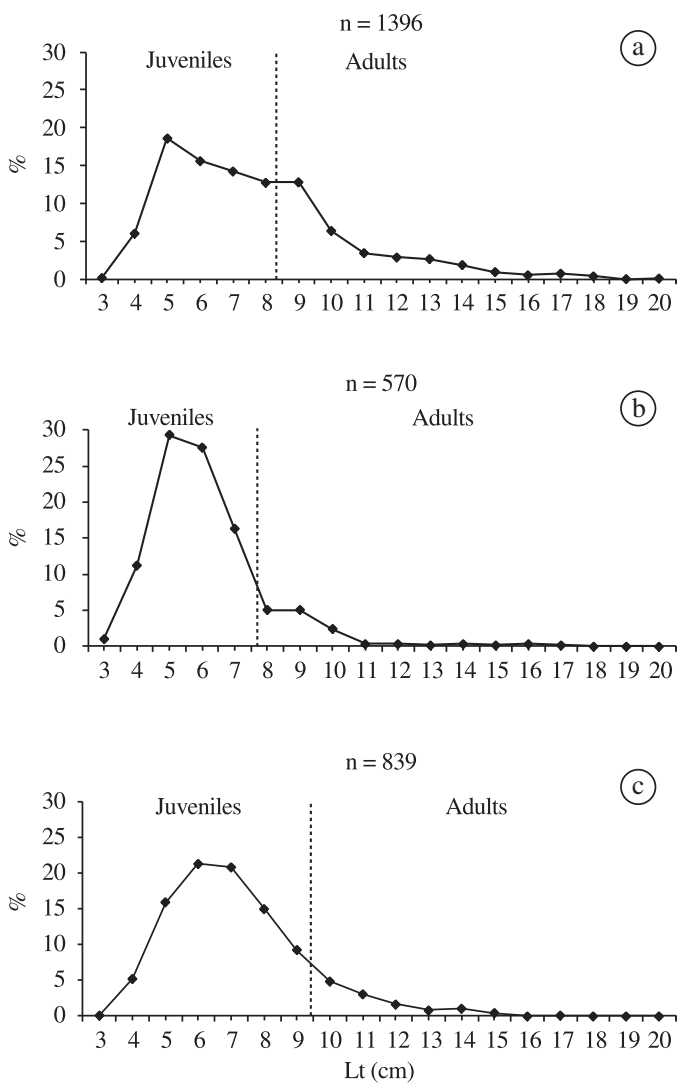

Figure 8. Distribution of frequency (\%) of length of Stellifer rastrifer, Stellifer stellifer and Stellifer brasiliensis overlapped to the female's size of the first maturity.

that of S. rastrifer, values from accumulated captures enabled Pauly (1984) to make a reliable analysis of the structures of these populations.

According to Nikolsky (1969), the composition of a population in different length classes is a function of environmental change and may vary according to population fertility. In this present case, variations become more distinct in different seasons of the year, since it can be observed that, for the three species, summer is the time of recruitment of the young ones, so that a greater number of larger individuals were seen in the spring, corroborating what was reported by Giannini and Paiva-Filho (1990b) and Almeida and Branco (2002).

The high number of juveniles present in the trawls can be attributed to the low selectivity of gear and, when compared to length data for S. rastrifer (Coelho et al., 1985; Giannini and Paiva-Filho, 1990b), S. stellifer (Almeida and Branco, 2002) and S. brasiliensis (Coelho et al., 1987; Giannini and Paiva-Filho, 1995), an increased fishing pressure from the lower strata of the population can be observed in Armação do Itapocoroy than elsewhere. By overlapping the female's size of sexual maturity $\left(\mathrm{L}_{50}\right)$ with the frequency distribution of length, the impact of fishing of juveniles is highlighted. This can compromise the maintenance of fish stocks of these populations (Diamond et al., 2000). On the other hand, a greater impact on adults of S. rastrifer (33\%) compared to that of S. brasiliensis (13\%) and S. stellifer (10\%), can probably be a reproductive advantage over other species because these individuals might have already participated in one reproductive period assisting in the maintenance of its population.

The fact that males Stellifer spp. reach sizes at first maturity less than those of females appears to be related to the tendency of these invest more resources in the formation of gametes (Futuyma, 1992). This is recorded for most marine sciaenids (Lowerre-Barbieri et al., 1996; Hutchings et al., 2006).

The sizes at first maturity $\left(\mathrm{L}_{50}\right)$ estimated for the species S. rastrifer and S. stellifer were lower than those recorded by Coelho et al. (1985) and Almeida and Branco (2002) respectively, whereas $S$. brasiliensis showed a value of $\mathrm{L}_{50}$ greater than those estimated by Coelho et al. (1987). Such changes in the estimated values of $\mathrm{L}_{50}$ reported here may be related to intraspecific variations due to environmental conditions such as temperature, availability of food or influence of fishing on these populations (Vazzoler, 1996).

The characterisation of the reproductive cycle is essential for understanding the dynamics of fish populations and the establishment of programmes for management of exploited ecosystems. The gonadosomatic index (GSI) and reproductive activity (RAI) associated with the information of maturation stages showed that spring is the main breeding season of Stellifer spp., confirming the findings of Longhurst and Pauly (2007) for tropical fish and by different authors for individuals of genus Stellifer (Chaves and Vendel, 1997; Gianini and Paiva-Filho, 1990b; Almeida and Branco, 2002; Sousa and Chaves, 2007). The decrease in reproductive activity occurred in the summer for all species of this genus. However $S$. rastrifer remained with moderate reproductive activity values at this season, indicating that their reproductive period, besides being more pronounced in spring, extends for a longer period of time than the other species.

Considering that the genus Stellifer have gonads with the presence of follicles at different stages of development and multiple spawning (Chaves and Vendel, 1997), as well as weekly maturation of the gonads, we chose to use the reproductive stage $\mathrm{B}$ (Maturing) indicative of reproductive activity. This method proved effective, as confirmed by the GSI variations, represented by small increases in value during the months prior to the main reproduction period for the species.

The catches were mainly composed of females and, as mentioned by Coelho et al. (1987), this higher bycatch of females could, over the years, causes great damage to the population, since the abundance of females is the main factor contributing to the reproductive potential of a population. According Nikolsky (1963), the ratio of females is greater when the food availability is abundant, which appears to occur in the present study, since the water mass in the Armação do Itapocoroy is influenced by nutrient input Itajai-Açu river (Schettini et al., 1999). In a study in the Sepetiba Bay, Vicentini and Araujo (2003) reported 

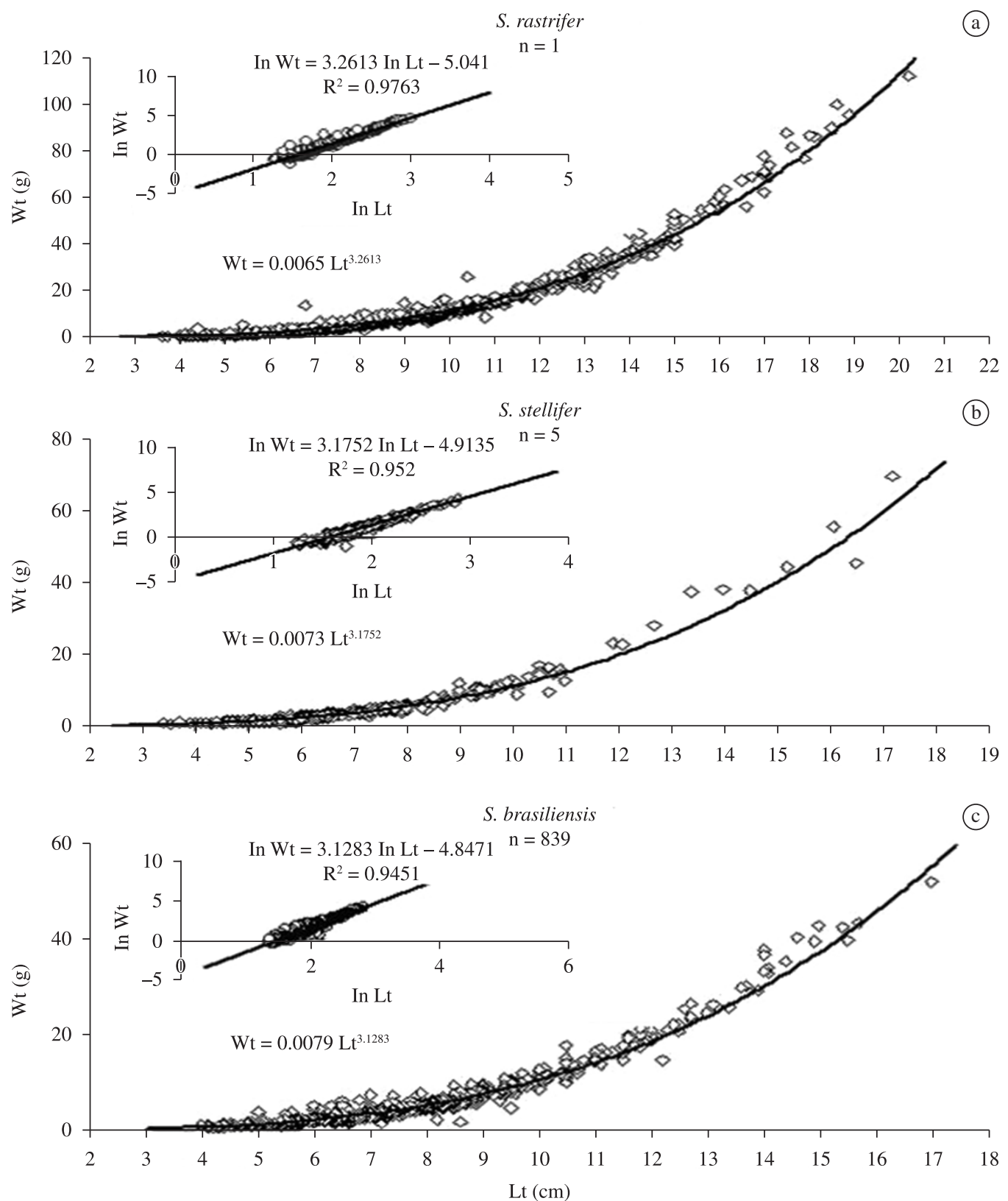

Figure 9. Weight/length relationships (a) and linear relationship (b) of the population of Stellifer rastrifer, Stellifer stellifer and Stellifer brasiliensis captured in Armação do Itapocoroy.

similar results, with the largest proportions of sciaenid females recorded in the areas containing high amounts of organic material.

Relationships between weight and length of species are important in promoting the exploitation and management of species of importance to fisheries (Santos, 1978; Anderson and Gutreuter, 1983). The growth patterns for the Stellifer species were allometric positive $(b>3.0)$, as found in the works of Coelho et al. (1985), Gianinni and Paiva-Filho (1990b), Gianinni and Paiva-Filho (1995), Chaves and Vendel (1997) and Almeida and Branco (2002).
The condition factor $(\mathrm{K})$ is widely used in the study of fish biology and may indicate how the animal explores the energetic resources on the assumption that individuals with greater mass in a given period are in better physiological conditions (Le Cren, 1951; Lima-Junior and Goitein, 2006). The association between the variations of condition factor and reproduction in fish has been mentioned by Barbieri and Verani (1987) and Vazzoler (1996) and for individuals of the genus Stellifer spp. by Chaves and Vendel (1997). In this study, there was an increase in condition factor before the main breeding period, indicating that individuals store reserves to support future energy losses. The considerable 


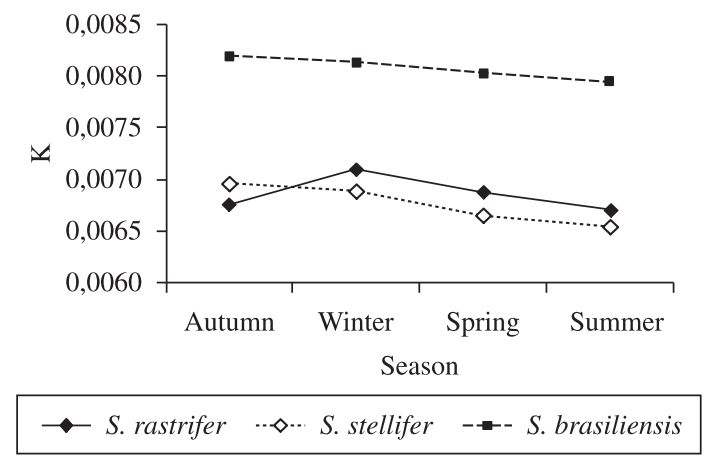

Figure 10. Variations in the average value of total condition factor Stellifer rastrifer, Stellifer stellifer and Stellifer brasiliensis in the different seasons of the year.

fall in values of condition factor in the aftermath of reproduction shows the intense metabolic expenditure in the process and its subsequent reorganization of gonads.

The used of average relative condition factor $\left(\mathrm{K}_{\mathrm{r}}\right)$ enabled the comparison with the estimated central value 1.0 , regardless of species and population size, allowing the monitoring of feeding activity of the species, verifying whether or not it is making appropriate use of their food resources (Anderson and Gutreuter, 1983). This factor reflects the physiological status of the individual, providing information for comparing two or more populations living under the same conditions (Weatherley and Gill, 1987).

According to the results presented here, it can be inferred that the population of $S$. brasiliensis is using the food resources in the study area most effectively. The population of $S$. rastrifer obtained values of $\mathrm{K}_{r}>1$, and is thus also subject to favourable conditions for growth, while for S. stellifer, $\mathrm{K}_{\mathrm{r}}<1$, indicating that the latter species is subjected to unfavourable conditions for growth or even stress in the studied region.

Frehse (2009) found that for S. rastrifer and $S$. brasiliensis, despite consuming largely the same resources, have different feedings strategies, as supported the values greater than 1.0 for the condition factor of these populations, indicating the occurrence of overlapping niches and interspecific competition between them. However their coexistence is made possible due to different feeding strategies, reducing competition for resources. Anatomical differences are related to the choice of optimal food for a species (Futuyma, 1992), as evidenced by an oblique and terminal mouth of $S$. rastrifer and quasi-ventral and subterminal mouth of S. brasiliensis (Menezes and Figueiredo, 1980), which appears to influence the composition of benthic food predominant for $S$. brasiliensis and pelagic S. rastrifer (Frehse, 2009).

In this context, it appears that the niche overlap and the interspecific competition between S. rastrifer and S. stellifer are more accentuated by the similarity of the oral apparatus (Menezes and Figueiredo, 1980), resulting in disadvantages to both species, especially for $S$. stellifer due to reproductive characteristics of $S$. rastrifer that provides maintenance of the a larger population, supporting the lowest values of relative condition factor obtained from them.

The previous results on the trophic ecology of fishes associated with seabob shrimp on the coast of Santa Catarina confirmed the sharing of food items in the diet of S. rastrifer and S. Stellifer (Branco, personal communication). However, such species should only share some resources, not being limited by the same, different enough to allow the coexistence of species of the genus Stellifer spp. in the same habitat (Gause, 1934; Hutchinson, 1978).

An overlapping niche denotes redundant ecological functions in the ecosystem and an increase in competition among species (Abrams, 1983). However, this overlap can increase the resilience of the environment. According to Rosenfeld (2002), functional redundancy is based on the observation that species with similar tasks in the biota, and their replacement may damage sensitive ecosystem processes.

Our results demonstrate that even though the genus Stellifer spp. shares the same habitat, S. rastrifer's reproductive strategies and population aspects will provide its population with ecological advantages against others, helping to maintain a greater abundance. According Siepielski and McPeek (2010), myriad ecological processes can promote or hinder species coexistence, but the capacity to increase when it is rare and the others are at their typical abundances (Invasibility) is the hallmark of all mechanisms promoting species coexistence. Thus, the low abundances of $S$. brasiliensis and, especially, S. stellifer apparently cause demographic advantages to these populations and satisfies the invasibility criterion, allowed the coexistence of the species in the study area.

Acknowledgements - The authors would like to thank Federal University of São Carlos (UFSCar) Programme in Ecology and Natural Resources and the UNIVALI Office of Graduate Research, Extension and Culture for their support; $\mathrm{CNPq}$ for research project grants; and CAPES for Jorge Luiz Rodrigues Filho's graduate scholarship.

\section{References}

ABRAMS, P., 1983. The theory of limiting similarity. Annual Review of Ecology and Systematics, vol. 14, p. 359-376. http:// dx.doi.org/:10.1146/annurev.es.14.110183.002043

AGOSTINHO, AA., MENDES, VP., SUZUKI, HI. and CANZI, C., 1993. Avaliação da atividade reprodutiva da comunidade de peixes dos primeiros quilômetros a jusante do reservatório de Itaipu. Unimar, vol. 15, supl., p. 175-189.

ALMEIDA, LR. and BRANCO, JO., 2002. Aspectos biológicos de Stelliferstellifer na pesca artesanal do camarão sete-barbas, Armação do Itapocoroy, Penha, Santa Catarina, Brasil. Revista Brasileira de Zoologia, Curitiba, vol. 19, no. 2, p. 601-610.

ANDERSON, R. and GUTREUTER, S.,1983. Length, weight and associated structural indices. In NIELSEN L. and JOHNSON, D. (Eds). Fisheries Techniques. Columbus: American Fisheries Society Publications. p. 283-300. 
BARBIERI, G. and VERANI, JR., 1987. O fator de condição como indicador do período de desova em Hypostomusaff. Plecostomus (Linnaeus, 1758) (Osteichthyes, Loricariidae), na represa do Monjolinho (São Carlos, SP). Ciência e Cultura, Campinas, vol. 39, p. 655-658.

BRANCO, JO. and VERANI, JR., 2006. Análise quali-quantitativa da ictiofauna acompanhante na pesca do camarão sete-barbas, na Armação do Itapocoroy, Penha, Santa Catarina. Revista Brasileira de Zoologia, Curitiba, vol. 23, no. 2, p. 381-391.

CHAVES, PTC. and VENDEL, AL., 1997. Reprodução de Stelliferrastrifer (Jordan) (Teleostei, Sciaenidae) na baía de Guaratuba, Paraná, Brasil. Revista Brasileira de Zoologia. Curitiba, vol. 14 , no. 1, p. 81-89.

-, 1998. Feeding habits of Stelliferrastrifer (Perciformes, Sciaenidae) at Guanabara Mangrove, Paraná, Brazil. Brazilian Archives of Biology and Technology, vol. 41, no. 4, p. 423-428.

COELHO, JAP., GRAÇA-LOPES, R., RODRIGUES, ES. and PUZZI, A., 1985. Relação peso-comprimento e tamanho de início de primeira maturação gonadal para o SciaenidaeStelliferrastrifer (Jordan, 1889), no litoral do Estado de São Paulo. Boletim do Instituto de Pesca, São Paulo, vol. 12, no. 2, p. 99-107.

COELHO, JAP., GRAÇA-LOPES, R., RODRIGUES, ES. and PUZZI, A., 1987. Aspectos biológicos e pesqueiros do SciaenidaeStellifer brasiliensis (Schultz, 1945), presente na pesca artesanal dirigida ao camarão sete-barbas (São Paulo, Brasil). Boletim do Instituto de Pesca, São Paulo, vol. 14, p. 1-10.

DIAMOND, SL., COWELL, LG. and CROWDER, LB., 2000. Population effects of shrimp trawl bycatch on Atlantic croaker. Canadian Journal of Fisheries Aquatic Science, vol. 57, p. 20102021. http://dx.doi.org/10.1139/cjfas-57-10-2010

FREHSE, FA., 2009. Estrutura populacional e dieta de Stelliferrastrifer (Jordan, 1889) e Stellifer brasiliensis (Schultz, 1945) (Sciaenidae, Perciformes), nos períodos diurno e noturno, em quatro áreas da plataforma sul do Estado do Paraná e norte do Estado de Santa Catarina. Curitiba: Universidade Federal do Paraná. 66 p. Dissertação de Mestrado em Ciências Biológicas - Zoologia.

FROESE, R. and PAULY, D. (Eds.), 2010. FishBase. Version (01/2010). Available from: <www.fishbase.org>

FUTUYMA, DJ., 1992. Biologia Evolutiva. Ribeirão Preto: Sociedade Brasileira de Genética. 631 p.

GALBRAITH, RD., RICE, A. and STRANGE, ES., 2004. An introduction to commercial fishing gear and methods used in Scotland. Fisheries research services, Scottish Fisheries information pamphlet, no. 25, p. 1-43.

GAUSE, GF., 1934. The struggle for existence. New York, Hafner. 163 p.

GIANNINI, R. and PAIVA-FILHO, AM., 1990a. Os Sciaenidae (Teleostei: Perciformes) da Baía de Santos (SP), Brasil. Boletim do Instituto Oceanográfico, São Paulo, vol. 38, no. 1, p. 69-86.

-, 1990b. Aspectos bioecológicos de Stelliferrastrifer (Perciformes: Sciaenidae) na Baía de Santos, SP. Boletim Instituto de Pesca, São Paulo, vol. 38, no. 1, p. 57-67.

-, 1995. Distribuição temporal, espacial e bioecologia do cangoá, Stellifer brasiliensis (Teleostei: Sciaenidae), na Baía de Santos, São Paulo, Brasil. Arquivos Ciências do Mar, Fortaleza, vol. 29, no. 1-2, p. 5-15.
GRAÇA-LOPES, R., TOMÁS, ARG., TUTUI, SLS., SEVERINORODRIGUES, E. and PUZZI, A., 2002. Fauna acompanhante da pesca camaroeira no litoral do estado de São Paulo, Brasil. Boletim do Instituto de Pesca, vol. 28, no.2, p. 173-188.

HUTCHINGS, KM. GRIFFITHS, H. and FIELD, JG.,2006. Regional variation in the life history of the canary drumUmbrina. Fisheries Research, vol. 77, p. 312-325. http://dx.doi.org/10.1016/j. fishres.2005.10.011

HUTCHINSON, GE., 1978. An Introduction to Population Ecology. New Haven: Yale University Press. 260 p.

LE CREN, ED., 1951. The length - weight relationship and seasonal cycle in gonad weight and condition in the perch (Percafluviatilis). Journalof Animal Ecology, Oxford, vol. 20, no.2, p. 201-219.

LIMA-JUNIOR, SE. and GOITEIN, R., 2006. Fator de Condição e ciclo gonadal de fêmeas de Pimelodusmaculatus (Osteichthyes, Pimelodidae) no rio Piracicaba (SP, Brasil). Boletim do Instituto de Pesca, vol. 32, no. 1, p. 87-94.

LONGHURST, AR. and PAULY, D., 2007. Ecologia dos oceanos tropicais. São Paulo: Editora da Universidade de São Paulo.

LOWERRE-BARBIERI, SK., CHITTENDEN JUNIOR, ME. and BARBIERI, LR., 1996. The multiple spawning pattern of weakfish in the Chesapeake Bay and Middle Atlantic Bight. Journal of Fish Biology, vol. 48, p. 1139-1163. http://dx.doi. org/10.1111/j.1095-8649.1996.tb01811.x

MENEZES, N. and FIGUEIREDO, JL., 1980. Manual de peixes marinhos do Sudeste do Brasil. IV. São Paulo: Museu de Zoologia, Universidade de São Paulo. 96p. Teleostei (3).

MENEZES, NA., BUCKUP, PA., FIGUEIREDO, JL. and MOURA, RL., 2003. Catálogo das espécies de peixes marinhos do Brasil. São Paulo:Museu de Zoologia, Universidade de São Paulo. 160 p.

NIKOLSKY, GV., 1963. The ecology of fishes. 6nd ed. London: Academic Press. 353p.

-, 1969. Theory of fish population dynamics. Edinburgh: Oliver and Boyd.323p.

PAULY, D. 1984. A mechanism for the juvenile-to-adult transition in fishes. Jornal Marine Science, vol. 41, p. 280-284.

PEARSON, ES., 1947. The choice of statistical tests illustrated on the interpretation of data classed in a $2 \times 2$ table. Biometrika, vol. 34, p. 139-167.

ROSENFELD, JS., 2002. Functional redundancy in ecology and conservation. Oikos, vol. 98, no. 1, p. 156-162.

SANTOS, EP., 1978. Dinâmica de Populações Aplicada à Pesca e Piscicultura. São Paulo: HUCITEC/EdUSP. 129p.

SCHETTINI, CAF., CARVALHO, JLB. and TRUCCOLO, EC., 1999. Aspectos hidrodinâmicos da enseada da Armação do Itapocoroy, SC. Notas Técnicas da FACIMAR, vol. 3, p. 99-109.

SOUSA, LM.and CHAVES, PTC., 2007. Atividade reprodutiva de peixes (Teleostei) e o defeso da pesca de arrasto no litoral norte de Santa Catarina, Brasil. Revista Brasileira de Zoologia, Curitiba, 24, 4: 1113-1121.

SOUZA, UP., COSTA, RC., MARTINS, IA. and FRANSOZO, A., 2008. Associações entre as biomassas de peixes Sciaenidae (Teleostei: Perciformes) e de camarões Penaeoidea (Decapoda: 
Dendrobranchiata) no litoral norte do Estado de São Paulo. Biota Neotropica, 8, 1: 83-92.

SIEPIELSKI, AM. and McPEEK, MA., 2010. On the evidence for species coexistence: a critique of the coexistence program. Ecology 91:3153-3164

VAZZOLER, AEAM., 1996. Biologia da reprodução de peixes teleósteos: teoria e prática. Maringá: EDUEM. 169p.
VICENTINI, RN. and ARAUJO, FG., 2003. Sex ratio and size structure of Micropogoniasfurnieri (Desmarest, 1823) (Perciformes, Sciaenidae) in Sepetiba Bay, Rio de Janeiro, Brazil. Brazilian Journal of Biology, vol. 63, n. 4, p. 559-566.

WEATHERLEY, AH. and GILL, HS., 1987. The Biology of Fish Growth. London: Academic Press.443p.

ZAR, JH. 1999. Biostatistical Analysis. 4nd ed. New Jersey: Prentice-Hall Inc. 663p. 